\title{
TINJAUAN PUSTAKA RETINAL DETACHMENT PADA PEDIATRI
}

\author{
Nur Fadlia Rahmani \\ Universitas Mataram, Indonesia \\ Email: nurfadlia2519@gmail.com
}

\begin{abstract}
Abstrak
Retina yang terletak di jaringan posterior berperan dalam mentransmisikan foton yang ditangkap kemudian digunakan sebagai sinyal listrik dan kimia bagi otak untuk melihat gambar visual. Adapun suatu kondisi ketika retina neurosensorik kehilangan perlekatan pada retinal pigment epithelium (RPE) disebut sebagai retinal detachment atau ablasi retina yang dapat mengakibatkan degenerasi fotoreseptor dan iskemia sehingga dapat menyebabkan kehilangan penglihatan secara permanen. Tujuan penelitian ini adalah untuk mengetahui retinal detachment pada pediatri. Umumnya terjadi pada usia lanjut, namun dapat juga terjadi pada anak-anak dengan prevalensi sekitar 0,5-8\% dari semua retinal detachment. Hasil penelitian ini menunjukkan jika retinal detachment dapat diklasifikasikan menjadi tiga yaitu, rhegmatogenous retinal detachment, tractional retinal detachment dan exudative retinal detachment. Adapun tatalaksana yang dapat dilakukan berupa pembedahan dan non pembedahan, dimana pembedahan umumnya dilakukan pada ablasio retina regmatogenosa dan traksi. Sedangkan pada ablasi retina eksudatif dapat dilakukan dengan tanpa pembedahan. Adapun kesimpulan yang bisa diambil dari penelitian ini adalah Retinal detachment atau ablasi retina merupakan suatu kondisi ketika retina neurosensorik kehilangan perlekatan pada retinal pigment epithelium (RPE) yang dapat terjadi pada bayi,anak-anak, terutama usia lanjut, dimana prevalensi pediatrik sekitar 0,5-8\% dari semua retinal detachment.
\end{abstract}

Kata kunci: Retina; Ablasi retina; Pediatri

\section{Abstract}

The retina, which is located in the posterior tissue, plays a role in transmitting photons that are captured and then used as electrical and chemical signals for the brain to see visual images. A condition in which the neurosensory retina loses its attachment to the retinal pigment epithelium (RPE) is known as retinal detachment retinal detachment or which can result in photoreceptor degeneration and ischemia that can lead to permanent vision loss. The purpose of this study was to determine retinal detachment in pediatrics. Generally occurs in the elderly, but can also occur in children with a prevalence of about 0.5-8\% of all retinal detachments. The results of this study indicate that retinal detachment can be classified into three, namely, rhegmatogenous retinal detachment, tractional retinal detachment and exudative retinal detachment. The treatment that can be done in the form of surgery and non-surgical, where surgery is generally performed on rhegmatogenous retinal detachment and traction. While the exudative retinal detachment can be done without surgery. The conclusions that 
can be drawn from this study is retinal detachment or retinal detachment is a condition when the neurosensory retina attachment loss in the retinal pigment epithelium (RPE), which can occur in infants, children, especially the elderly, where the prevalence of pediatric about $0.5-8 \%$ of all retinal detachments.

Keyword: Retina; Retinal detachment; Pediatric

Diterima: 21-12-2022

Direvisi: 13-01-2022

Diterbitkan: 20-01-2022

\section{Pendahuluan}

Retina terletak di jaringan posterior dan merupakan lapisan terdalam mata yang terdiri dari beberapa lapisan seluler. Retina berperan mentransmisikan foton yang ditangkap kemudian digunakan sebagai sinyal listrik dan kimia bagi otak untuk melihat gambar visual (Nguyen et al., 2021). Suatu kondisi ketika retina neurosensorik kehilangan perlekatan pada retinal pigment epithelium (RPE) disebut sebagai retinal detachment atau ablasi retina yang dapat mengakibatkan degenerasi fotoreseptor dan iskemia sehingga dapat menyebabkan kehilangan penglihatan secara permanen (Blair et al., 2021).

Umumnya retinal detachment terjadi pada usia lanjut walaupun begitu penyakit ini juga dapat ditemukan pada anak-anak(pediatri), dimana prevalensi pediatrik sekitar 0,5-8\% dari semua retinal detachment (McElnea et al., 2018). Retinal detachment diklasifikasikan menjadi tiga yaitu, rhegmatogenous retinal detachment, tractional retinal detachment dan exudative retinal detachment, dimana subtipe yang paling sering terjadi adalah rhegmatogenous retinal detachment (Nuzzi et al., 2017).

Etiologi dari retinal detachment sesuai dengan subtipe dan trauma okuler merupakan etiologi paling umum pada pediatric retina detachment (Yaşa et al., 2018). Adapun manifestasi klinis dari retinal detachment seperti lapang pandang yang semakin menurun secara lambat dan progresif, floaters, fotopsia dan leukokoria (Kanukollu \& Tripathy, 2021).

\section{Metode Penelitian}

Metode penelitian yang digunakan dalam pemecahan permasalahan termasuk metode analisis. Sumber data penelitian ini berasal dari literatur yang diperoleh melalui internet berupa hasil penelitian dari jurnal internasional dalam rentang waktu tahun 20112021.

\section{Pembahasan}

\section{A. Definisi}

Suatu kondisi ketika retina neurosensorik kehilangan perlekatan pada retinal pigment epithelium (RPE) disebut sebagai retinal detachment atau ablasi retina yang dapat mengakibatkan degenerasi fotoreseptor dan iskemia sehingga dapat menyebabkan kehilangan penglihatan secara permanen (Nguyen et al., 2021).

\section{B. Epidemiologi}


Pertahun terdapat sekitar 1:10.000-15.000 insiden retinal detachment dan umumnya sering pada usia $\geq 50$ tahun serta dengan jenis kelamin laki-laki dibandingkan perempuan. Walaupun umumnya terjadi pada usia lanjut retinal detachment juga dapat ditemukan pada anak-anak(pediatri), dimana prevalensi pediatrik sekitar 0,5-8\% dari semua retinal detachment (Josifovska et al., 2019).

\section{Etiologi}

Etiologi yang mendasari retinal detachment bergantung pada subtipenya. Pada ablasio retina regmatogenosa etiologinya antara lain, trauma, miopia patologis, ekskavasi retina perifer, operasi intraokular sebelumnya, retinal detachment pada mata disebelahnya dan ada anggota keluarga yang juga pernah mengalami. Pada ablasi retina traksi etiologinya antara lain, retinopati diabetik proliferatif, trauma, retinopati prematuritas, vitreotinopati proliferatif, dan oklusi vena retina. Pada ablasi retina eksudatif etiologinya antara lain, tumor mata primer, sifilis, toksoplasmosis, metastasis okular, dan sarcoidosis, oftalmia simpatik, nekrosis retina akut dan tuberkulosis (Blair et al., 2021).

Sedangkan pada pediatric retina detachment etiologi paling sering adalah trauma okuler, peradangan dan infeksi. Selain itu pada anak dapat bersifat kongenital termasuk kondisi vitreoretinal herediter yang langka, seperti vitreoretinopati eksudatif familial, sindrom Marfan, sindrom Stickler, incontinentia pigmenti, penyakit Norrie dan retinoschisis terkait-X. Patologi perkembangan seperti koloboma dan pembuluh darah janin yang persisten dapat menjadi etiologi ablasi retina pada bayi. Sedangkan pada bayi prematur dapat di sebabkan karena retinopati prematuritas (Badhwar et al., 2019).

\section{Patofisiologi dan Klasifikasi}

Terdapat tiga klasifikasi ablasi retina antara lain, ablasi retina regmatogenous, ablasi retina traksi, dan ablasi retina eksudatif.

\section{a. Ablasi Retina Regmatogenosa}

Pada saat retina memiliki lubang atau robekan disebut sebagai ablasi retina regmatogenosa. Ketika hal ini terjadi, menyebabkan pelepasan dari RPE dikarenakan cairan vitreous terus memasuki ruang di bawah retina neurosensorik sampai seluruh retina posterior terlepas. Durasi tergantung pada lokasi terjadinya ablasi, dapat terjadi selama berjam-jam hingga berbulan-bulan. Meskipun tanpa intervensi bedah ablasi retina dapat menyebabkan kehilangan penglihatan yang parah dan dapat menyebabkan kebutaan yang bersifat permanen (Association \& Health, 1985).

\section{b. Ablasi Retina Traksi}

Ablasi retina traksi terjadi ketika kekuatan membran proliferatif di permukaan retina atau di vitreous yang cukup kuat untuk melepaskan retina neurosensorik dari RPE. Pada kasus ablasi ini, tidak terdapat adanya kerusakan pada retina neurosensorik (Blair et al., 2021).

\section{c. Ablasi Retina Eksudatif}

Ablasi retina eksudatif atau serosa terjadi ketika adanya eksudasi cairan karena lesi besar seperti tumor atau mediator inflamasi yang menyebabkan terakumulasinya 
cairan subretina. Pada ablasi ini tidak terdapat adanya kerusakan pada retina neurosensorik (Iskandar et al., 2020).

\section{E. Diagnosis}

\section{a. Anamnesis}

Manifestasi klinis dari retinal detachment seperti lapang pandang yang semakin menurun secara lambat yang dimulai dari perifer ke sentral dan bersifat progresif. Selain itu, terdapat floaters, fotopsia strabismus dan leukokoria. Riwayat trauma okular dan riwayat operasi sebelumnya, prematuritas, infeksi, sindrom herediter yang melibatkan sistemik dapat menjadi faktor risiko (Nuzzi et al., 2017).

\section{b. Pemeriksaan Mata}

Pemeriksaan yang dapat dilakukan antara lain, pemeriksaan visus pada kedua mata untuk melihat apakah ada penurunan visus yang umum terjadi pada ablasi retina, refleks pupil untuk melihat apakah terdapat defek pupil aferen relatif, pemeriksaan konfrontasi visual, tekanan intra okular, pemeriksaan slit lamp untuk melihat apakah ada kelainan, funduskopi untuk melihat apakah ada schaffer sign (pigmen di vitreous anterior) dan pendarahan vitreous. Pada anak-anak sering ditemukan adanya anomaly mata berupa degenerasi kisi. Umumnya ditemukan kelainan patologis seperti miopia tinggi dan retinopati prematuritas (Nuzzi et al., 2017).

\section{c. Pemeriksaan penunjang}

Dapat dilakukan pemeriksaan USG dimana pada suatu penelitian meta analisis menunjukkan sensitivitas $94,2 \%$ dan spesifisitas 96,3\% dalam mendiagnosis ablasi retina. Selain itu dapat dilakukan optical coherence tomography (OCT) untuk menentukan jenis ablasi dan membedakannya dari patologi retina yang lain. Pemeriksaan OCT dilakukan jika alat tersebut tersedia (Gunawan, 2021).

\section{F. Tatalaksana}

Pembedahan umumnya dilakukan pada ablasio retina regmatogenosa dan traksi. Sedangkan pada ablasi retina eksudatif dapat dilakukan dengan tanpa pembedahan. Penutupan robekan pada pembedahan ablasi retina regmatogenosa dapat dilakukan dengan tiga teknik yaitu, vitrektomi pars plana dengan pengangkatan gel vitreous dengan mesin vitrektomi, gesper sklera dan retinopeksi pneumatik berupa gelembung gas intraocular yang di injeksi kedalam mata yang menimbulkan adhesi korioretinal terbentuk disekitar robekan dan penyerapan cairan subretina, serta dapat juga dilakukan kombinasi teknik tersebut. Pada terapi ablasi retina eksudatif dapat dilakukan dengan tanpa pembedahan perlu diidentifikasi dan terapi pengobatan pada penyakit, massa retina atau koroid yang mendasari (Blair dan Czyz, 2021).

\section{G. Komplikasi}

Pada $8-10 \%$ pasien yang melakukan perbaikan ablasi retina primer mengalami retinopati proliferatif (PVR) yang menyebabkan kegagalan pada perbaikan. Selain itu dapat terjadi traksi ekuator, pelepasan epitel non-pigmen dari pars plana, kontriksi retina, pendarahan vitreous dan ablasio koroid (Blair dan Czyz, 2021). 


\section{Kesimpulan}

Retinal detachment atau ablasi retina merupakan suatu kondisi ketika retina neurosensorik kehilangan perlekatan pada retinal pigment epithelium (RPE) yang dapat terjadi pada bayi,anak-anak, terutama usia lanjut, dimana prevalensi pediatrik sekitar 0,5$8 \%$ dari semua retinal detachment. Terdapat tiga klasifikasi ablasi retina antara lain, ablasi retina regmatogenous, ablasi retina traksi, dan ablasi retina eksudatif dimana etiologi, patofisiologi dan tatalaksana dilakukan berdasarkan jenis ablasi retina. Komplikasi yang dapat timbul berupa retinopati proliferatif (PVR) yang merupakan penyebab paling umum dari kegagalan perbaikan. 


\section{BIBLIOGRAFI}

Association, C. M., \& Health, N. I. of. (1985). CMAJ: Canadian Medical Association journal= Journal de l'Association medicale canadienne. Google Scholar

Badhwar, V., Yeo, D., Joshi, S., Wong, S. C., \& Reddy, M. A. (2019). An 11-month-old girl with a retinal detachment. Digital Journal of Ophthalmology: DJO, 25(2), 33. Google Scholar

Blair, K., Alhadi, S. A., \& Czyz, C. N. (2021). Globe rupture. StatPearls [Internet]. Google Scholar

Gunawan, D. (2021). Evaluasi shear wave elastography, fibroscan dan kecepatan aliran vena porta pada pasien non alcoholic fatty liver disease. Universitas Hasanuddin. Google Scholar

Iskandar, F., Surya, R., Sungkar, A., \& Anggriany, F. D. (2020). Kontroversi Persalinan Spontan pada Miopia Tinggi. Cermin Dunia Kedokteran, 47(12), 779-780. Google Scholar

Josifovska, N., Lumi, X., Szatmari-Tóth, M., Kristóf, E., Russell, G., Nagymihály, R., Anisimova, N., Malyugin, B., Kolko, M., \& Ivastinović, D. (2019). Clinical and molecular markers in retinal detachment-From hyperreflective points to stem cells and inflammation. PloS One, 14(6), e0217548. Google Scholar

Kanukollu, V. M., \& Tripathy, K. (2021). Leukocoria. StatPearls [Internet]. Google Scholar

McElnea, E., Stephenson, K., Gilmore, S., O’Keefe, M., \& Keegan, D. (2018). Paediatric retinal detachment: aetiology, characteristics and outcomes. International Journal of Ophthalmology, 11(2), 262. Google Scholar

Nguyen, K. H., Patel, B. C., \& Tadi, P. (2021). Anatomy, head and neck, eye retina. StatPearls [Internet]. Google Scholar

Nuzzi, R., Lavia, C., \& Spinetta, R. (2017). Paediatric retinal detachment: a review. International Journal of Ophthalmology, 10(10), 1592. Google Scholar

Yaşa, D., Erdem, Z. G., Ürdem, U., Demir, G., Demircan, A., \& Alkın, Z. (2018). Pediatric traumatic retinal detachment: clinical features, prognostic factors, and surgical outcomes. Journal of Ophthalmology, 2018. Google Scholar

\section{First publication right:}

Jurnal Syntax Fusion: Jurnal Nasional Indonesia

This article is licensed under:

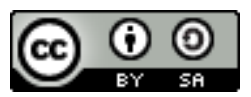

